\title{
OPEN Author Correction: Water sports could contribute to the translocation of ranaviruses
}

\section{Rosa Casais, Asier R. Larrinaga, Kevin P. Dalton, Paula Domínguez Lapido, Isabel Márquez, Eloy Bécares, E. Davis Carter, Matthew J. Gray, Debra L. Miller \& Ana Balseiro}

Correction to: Scientific Reports https://doi.org/10.1038/s41598-019-39674-5, published online 20 February 2019

The Acknowledgements section in this Article is incomplete.

“This study was partially funded by the Principado de Asturias, PCTI 2018-2020 (GRUPIN: IDI2018-000237) and FEDER. We thank Benjamin Rabanal from the Laboratorio de Técnicas Instrumentales, University of León, for Batrachochytrium spp. PCR analysis, and Frank Pasmans' Lab for kindly providing Bd and Bsal DNA controls."

should read:

“This study was partially funded by the Principado de Asturias, PCTI 2018-2020 (GRUPIN: IDI2018-000237) and FEDER. We thank Benjamin Rabanal from the Laboratorio de Técnicas Instrumentales, University of León, for Batrachochytrium spp. PCR analysis, and Frank Pasmans' Lab for kindly providing Bd and Bsal DNA controls.

Fieldwork was partially funded by the Environment and Land Planning Department of the Regional Government of Galicia (Xunta de Galicia), with the financial support of the European Agricultural Fund for Rural Development (EAFRD) of the European Union. We are indebted to the Galician Canoeing Federation for their help and support during the field work."

(1) Open Access This article is licensed under a Creative Commons Attribution 4.0 International License, which permits use, sharing, adaptation, distribution and reproduction in any medium or format, as long as you give appropriate credit to the original author(s) and the source, provide a link to the Creative Commons licence, and indicate if changes were made. The images or other third party material in this article are included in the article's Creative Commons licence, unless indicated otherwise in a credit line to the material. If material is not included in the article's Creative Commons licence and your intended use is not permitted by statutory regulation or exceeds the permitted use, you will need to obtain permission directly from the copyright holder. To view a copy of this licence, visit http://creativecommons.org/licenses/by/4.0/.

(C) The Author(s) 2020 